\title{
ANALISIS NERACA SUMBER DAYA AIR BERBASIS SISTEM INFORMASI GEOGRAFIS (SIG) (Studi Kasus pada DAS Ngunggahan)
}

\author{
Yopi Adi Firmanda ${ }^{1}$, Rintis Hadiani ${ }^{2)}$, Agus Prijadi Saido ${ }^{3)}$ \\ 1) Mahasiswa Fakultas Teknik, Prodi Teknik Sipil, Universitas Sebelas Maret \\ 2) Pengajar Fakultas Teknik, Prodi Teknik Sipil, Universitas Sebelas Maret \\ 3) Pengajar Fakultas Teknik, Prodi Teknik Sipil, Universitas Sebelas Maret \\ Jl. Ir. Sutami 36A, Surakarta 57126; Telp. 0271-634524. Email: yopifirmanda@gmail.com
}

\begin{abstract}
The development of an area is directly proportional to the level of population growth and increasing water demand. One of them is the Ngunggahan watershed which flow into the Wonogiri reservoir. This phenomenon is not compatible with the availability of water, the amount will either remain constant or decrease over time. The lack of information and inappropriate management make the water requirements in the Ngunggahan watershed unfulfilled. This study aimed to create a water resources balance sheet map in 2019 based on GIS (Geographic Information System). The method used for the simulation of water discharge was Mock 15 daily by dividing the watershed into 3 small Sub-watersheds.

The results of the study showed two different water balance. The water balance in 2019 with the assumption that all water requirements was fulfilled from river discharge showed deficiency in all watersheds. Sub-watershed 1 had water availability of 1517,79 $\times 10^{8}$ liters/year and water needs of 5695,45 $\times 10^{8}$ liters/year, Sub-watershed 2 had water availability of 640,89 $\times 10^{8}$ liters/year and water needs of $2876,95 \times 10^{8}$ liters/year, Sub-watershed 3 had water availability of 439,69 $\times 10^{8}$ liters / year and water needs of $1315,31 \times 10^{8}$ liters/year. Therefore the map was red in all sub-watersheds sheet. While the water balance without considering irrigation water was also calculated with the assumption that the need for irrigation water was fulfilled from Parangiobo and Kedunguling reservoir. The results of calculations showed that Sub-watershed 1 had water availability of $1517,79 \times 10^{8}$ liters/year and water needs of 1439,02 $\times 10^{8}$ liters/year, Sub-watershed 2 had water availability of 934,80 $\times 10^{8}$ liters / year and water needs of 1062,18 $\times$ $10^{8}$ liters /year, Sub-watershed 3 had water availability 733,60 $\times 10^{8}$ liters/year and water needs 372,05 $\times 10^{8}$ liters/year. Therefore the maps were orange in Sub-watersheds 1 and 3, while it was red in Sub-watersheds 2.
\end{abstract}

Keywords: Water Resources Balance, Mock Method, GIS (Geographic Information System).

\begin{abstract}
Abstrak
Perkembangan suatu daerah berbanding lurus dengan tingkat pertumbuhan penduduk serta meningkatnya kebutuhan air. Salah satunya adalah DAS Ngunggahan yang bermuara di waduk Wonogiri. Fenomena ini tidak sejalan dengan ketersediaan air yang semakin lama jumlahnya tetap, bahkan berkurang. Minimnya informasi serta pengelolaan yang kurang tepat membuat tidak terpenuhinya kebutuhan air pada DAS Ngunggahan. Penelitian ini mencoba membuat peta neraca sumber daya air tahun 2019 berbasis SIG (Sistem Informasi Geografis). Metode yang digunakan untuk simulasi debit adalah Mock 15 harian dengan membagi DAS menjadi 3 sub DAS kecil. Hasil dari penelitian menunjukkan terjadinya dua neraca yang berbeda. Neraca sumber daya air tahun 2019 dengan asumsi semua kebutuhan air dipenuhi dari debit sungai menunjukkan terjadinya defisit disemua Sub DAS. Sub DAS 1 memiliki ketersediaan air sebesar 1517,79 x $10^{8}$ liter/tahun dan kebutuhan air 5695,45 x $10^{8}$ liter/tahun, Sub DAS 2 memiliki ketersediaan air 640,887 x $10^{8}$ liter/tahun dan kebutuhan air 2876,95 x $10^{8}$ liter/ tahun, Sub DAS 3 memiliki ketersediaan air 439,69 x $10^{8}$ liter/ tahun dan kebutuhan air 1315,31 x $10^{8}$ liter/ tahun. Sehingga peta berwarna merah disemua Sub DAS. Sedangkan neraca sumber daya air tanpa mempertimbangkan air irigasi juga dihitung dengan asumsi kebutuhan air irigasi dipenuhi dari waduk Parangjoho dan Kedunguling. Hasil perhitungan menunjukkan Sub DAS 1 memiliki ketersediaan air 1517,79 x $10^{8}$ liter/ tahun dan kebutuhan air $1439,02 \times 10^{8}$ liter/ tahun, Sub DAS 2 memiliki ketersediaan air 934,80 × $10^{8}$ liter/ tahun dan kebutuhan air 1062,18 x $10^{8}$ liter/tahun, Sub DAS 3 memiliki ketersediaan air 733,60 x $10^{8}$ liter/tahun dan kebutuhan air 372,05 x $10^{8}$ liter/ tahun. Sehingga peta berwarna oranye pada Sub DAS 1 dan 3, sedangkan Sub DAS 2 berwarna merah.
\end{abstract}

Kata Kunci : Neraca Sumber Daya Air, Metode Mock, SIG (Sistem Informasi Geografis) 


\section{PENDAHULUAN}

Perkembangan suatu daerah berbanding lurus dengan tingkat pertumbuhan penduduk serta meningkatnya kebutuhan hidup. Salah satunya adalah kebutuhan akan air. Setiap aktivitas dan pemenuhan kebutuhan pangan manusia tidak bisa terlepas dari air. Manusia tidak bisa mengelak atas tuntutan tersebut, namun harus dapat memaksimalkan setiap potensi/sumber daya yang ada dengan baik (Indra, 2011).

Kenyataan dilapangan menujukkan bahwa manusia belum bisa mendayagunakan air dengan baik. Terbukti dengan terjadinya bencana banjir saat musim penghujan dan kekeringan saat musim kemarau. Air permukaan masih menjadi pilihan utama dalam pemenuhan kebutuhan air, misal untuk irigasi, perikanan dan kebutuhan rumah tangga. Disamping itu, ada ketidakseimbangan antara tingkat ketersediaan air dan tingkat kebutuhan air diwaktu-waktu tertentu.

Daerah Aliran Sungai (DAS) Ngunggahan merupakan salah satu Sub DAS hulu dari DAS Bengawan Solo yang bermuara di waduk Wonogiri. Terletak di Kabupaten Wonogiri bagian barat. Secara geografis berada diantara 757’32,55” LS - 11050’40,15” BT. Luas DAS sebesar 49,97 km². DAS Ngunggahan memberikan kontribusi terhadap pemenuhan kebutuhan air didalam DAS juga terhadap debit yang masuk kedalam waduk Wonogiri. Apabila debit yang tersedia tidak bisa mencukupi tingkat kebutuhan air di DAS Ngunggahan, maka dapat berdampak buruk pada aktivitas pemenuhan kehidupan di DAS Ngunggahan dan debit yang masuk ke Waduk Wonogiri. Hal ini yang mengakibatkan bencana kekeringan.

Mahendra (2013) pernah melakukan penelitian tentang neraca air di DAS Ngunggahan, namun tidak sampai pada pembuatan peta. Penelitian kali ini mencoba memberikan kebaharuan informasi neraca air dan juga menyajikannya dalam bentuk peta yang berbasis Sistem Informasi Geografis (SIG). Saat ini penginformasian sungai berbasis digital Geographic Information System (GIS) sangat dibutuhkan semua kalangan, baik itu masyarakat maupun instansi pemerintah. Harapannya, hasil yang didapatkan bisa membantu proses pengambilan keputusan dalam rangka pengelolaan sumber daya air di DAS Ngunggahan.

\section{LANDASAN TEORI}

Air merupakan sumber daya alam esensial, yang sangat dibutuhkan oleh manusia dan makhluk hidup lainnya. Dengan air, maka bumi menjadi planet dalam tata surya yang memiliki kehidupan. Air bertransformasi melalui daur hidrologi (Kodoatie dan Sjarief, 2010).

Sebagai sistem hidrologi, Daerah Aliran Sungai (DAS) menerima input berupa hujan kemudian memprosesnya sesuai dengan karakteristiknya menjadi aliran. Hujan yang jatuh dalam satu DAS sebagian akan jatuh pada permukaan vegetasi, permukaan tanah atau badan air (Triatmodjo, 2010).

Masalah dalam suatu DAS adalah kekritisan air yang berdampak pada bagian hulu, tengah maupun hilir. Kaitan antara proses hidrologi dengan sistem DAS digambarkan dengan hubungan antara hujan sebagai imput dan aliran sebagai output-nya (Purnama, et al., 2012). Apabila dalam suatu DAS input lebih kecil dari pada output, maka bisa dikatakan DAS tersebut pada kondisi defisit air.

Simulasi Mock merupakan model hidrologi yang digunakan untuk menganalisis sistem DAS sebagai respon hidrologi. Keuntungan model ini adalah hasil analisis yang akurat, karena banyak memperhitungan faktor keadaan alam. Sedangkan parameter yang dicari juga banyak, membuat tidak dapat digunakannya metode ini apabila data tidak lengkap. Berdasarkan penelitian yang dilakukan oleh Suncaka (2013), simulasi hujan-debit metode Mock 15 harian memiliki keandalan yang tinggi dibanding dengan 5, 10 atau 30 harian dengan korelasi yang perbedaannya tidak terlalu signifikan.

Neraca air merupakan selisih antara ketersediaan air (input) dengan aliran (output) yang keluar pada suatu sistem tertentu (Harto, 2000). Penelitian yang dilakukan sebelumnya oleh Mahendra (2013) tentang neraca air di DAS Ngunggahan perlu diperbaharui demi memberikan kebaharuan informasi kepada masyarakat dan instansi terkait.

\section{Hujan Prediksi Metode Seasonal Auto Regression Integrated Moving Average (SARIMA)}

Penilitian ini akan memprediksi curah hujan tahun 2018 dan 2019. Metode yang dipakai untuk memprediksi curah hujan adalah metode Seasonal Auto Regression Integrated Moving Average (SARIMA). Metode SARIMA adalah suatu time series $\{\mathrm{Z} \mathrm{t} \mid \mathrm{t}=1,2, \ldots, \mathrm{k}\}$ dibangkitkan dari proses $(\mathrm{p}, \mathrm{d}, \mathrm{q})(\mathrm{P}, \mathrm{D}, \mathrm{Q}) \mathrm{s}$, dengan $(\mathrm{p}, \mathrm{d}, \mathrm{q})$ bagian yang tidak musiman, $(\mathrm{P}, \mathrm{D}, \mathrm{Q}) \mathrm{s}$ bagian yang musiman dan "s"adalah jumlah periode per musim. Persamaan SARIMA dapat dituliskan sebgai berikut :

$$
\emptyset_{P} B^{S} \emptyset_{P}(B)(1-B)^{d}\left(1-B^{S}\right)^{D} Z_{t}=\theta_{q}(B) \Theta_{q}\left(B^{S}\right) a_{t}
$$




$$
\begin{array}{ll}
\text { dimana, } & \\
\emptyset_{P}\left(B^{S}\right) & =\text { AR seasonal, } \\
\emptyset_{P}(B) & =\text { AR non-seasonal, } \\
(1-B)^{d} & =\text { differencing non-seasonal, } \\
\left(1-B^{S}\right)^{D} & =\text { differencing seasonal, } \\
\theta_{q}(B) & =M A \text { non-seasonal, } \\
\Theta_{q}\left(B^{S}\right) & =M A \text { seasonal, } \\
a_{t .} & =\text { nilai residual } \text { pada saat } \mathrm{t}, \\
Z_{t} & =\text { data time series } \text { pada waktu ke t. }
\end{array}
$$

\section{Simulasi Hujan-Debit Metode Mock}

Model Mock digunakan untuk mengubah curah hujan dengan mempertimbangkan evapotranspirasi, kelembaban dan penyimpanan tanah menjadi debit aliran (Mock, 1973). Penelitian ini menggunakan metode Mock 15 harian karena berdasarkan penelitian yang dilakukan oleh Suncaka (2013), metode Mock 15 harian cukup andal dibanding dengan metode Mock 5, 10 atau 30 harian.

Langkah perhitungan metode Mock yaitu :

- menghitung evapotranspirasi potensial

- $\quad$ menghitung limited evapotranspiration

- $\quad$ menghitung water balance

- menghitung aliran dasar dan limpasan langsung.

\section{Kebutuhan Air untuk Pemeliharaan Sungai}

Berdasarkan SNI 6728.1:2015 debit andalan 95\% digunakan untuk mengendalikan ketersediaan air sebagai upaya perlindungan aliran pemeliharaan sungai. Debit $95 \%$ adalah aliran air yang ada dalam $95 \%$ waktu pengamatan atau paling banyak kemungkinan hanya $5 \%$ aliran tersebut tidak tercapai.

\section{Kebutuhan Air untuk RKI (Rumah Tangga, Perkotaan dan Industri)}

Kebutuhan Air Rumah Tangga

Sebelum menghitung kebutuhan air untuk penduduk, perlu dihitung dulu proyeksi pertumbuhan penduduk pada tahun ke-n berdasarkan data dari Badan Pusat Statistik (BPS). Proyeksi pertumbuhan penduduk pada tahun ke-n bisa dicari dengan rumus berikut:

$P_{n}=P_{0}+\{1+(r \cdot n)\}$

dengan:

Pn = jumlah penduduk setelah $\mathrm{n}$ tahun ke depan,

Pn = jumlah penduduk pada tahun awal,

$\mathrm{r} \quad=$ angka pertumbuhan penduduk,

$\mathrm{n} \quad=$ jangka waktu dalam tahun.

Kebutuhan Air Perkotaan (Komersial dan Sosial) - Non Domestik

Berdasarkan SNI 6728.1:2015 kebutuhan air untuk perkotaan yang meliputi komersial dan sosial seperti toko, gudang, sekolah, rumah sakit, hotel dan sebagainya diasumsikan antara 15\% sampai 30\% dari total air pemakaian air bersih rumah tangga. Semakin padat jumlah penduduk maka semakin besar pula tingkat kebutuhan airnya.

Kebutuhan Air Industri

Berdasarkan SNI 6728.1:2015 kebutuhan air industri dapat diperhitungkan berdasarkan:

- jumlah karyawan,

- luas air industri,

- jenis/tipe industri.

\section{Kebutuhan Air Perikanan}

Beradasarkan SNI 6728.1:2015 kebutuhan air untuk perikanan dipengaruhi oleh luas kolam, jenis kolam dan kedalaman kolam. Rumus untuk menghitung kebutuhan air perikanan adalah sebagai berikut:

$Q_{f p}=\frac{q_{(f p)}}{1000} \times A_{(f p)} \times 10000$

Keterangan :

$Q_{f p}=$ kebutuhan air untuk perikanan ( $\mathrm{m}^{3} /$ hari), 
$q_{(f p)}=$ kebutuhan air untuk pembilasan (liter/hari/ha),

$A_{(f p)}=$ luas kolam ikan (ha).

\section{Kebutuhan Air Peternakan}

Beradasarkan SNI 6728.1:2015 kebutuhan air untuk peternakan memperhatikan jenis ternak dan jumlah ternak. Secara umum kebutuhan airnya bisa diestimasikan dengan persamaan sebagai berikut :

$Q_{e}=\left(q_{(1)} \times P_{(1)}+q_{(2)} \times P_{(2)}+q_{(3)} \times P_{(3)}\right)$

keterangan :

$\mathrm{Q}_{\mathrm{e}} \quad=$ kebutuhan air untuk ternak (liter/hari),

$\mathrm{q}_{(1)} \quad=$ kebutuhan air untuk sapi, kerbau dan kuda (liter/ekor/hari),

$\mathrm{q}_{(2)}=$ kebutuhan air untuk kambing dan domba (liter/ekor/hari),

$\mathrm{q}_{(3)}=$ kebutuhan air untuk unggas (liter/ekor/hari),

$\mathrm{P}_{(1)} \quad=$ jumlah sapi, kerbau dan kuda (ekor),

$\mathrm{P}_{(2)} \quad=$ jumlah kambing dan domba (ekor),

$P_{(3)} \quad=$ jumlah unggas (ekor).

\section{Kebutuhan Air untuk Irigasi}

Kebutuhan air untuk irigasi memperhatikan jadwal pola tanam, data areal tanam, evapotranspirasi acuan, hujan efektif, jenis tanah dan efisiensi saluaran irigasi. Hasil analisis kemudian dibandingan dengan data pengambilan dari bendung-bendung yang datanya tersedia.

Berdasarkan SNI 6728.1:2015, besarnya kebutuhan air irigasi dihitung berdasarkan persamaan sebagai berikut :

$I G=\frac{(E t c+I R+R W+P-E R)}{I E} \times A$

dengan:

IG = kebutuhan air irigasi $\left(\mathrm{m}^{3}\right)$,

Etc = kebutuhan air konsumtif ( $\mathrm{mm} /$ hari),

IR = kebutuhan air untuk penyiapan lahan $(\mathrm{mm} /$ hari),

RW = kebutuhan air untuk mengganti lapisan air ( $\mathrm{mm} /$ hari),

$\mathrm{P} \quad=$ perkolasi $(\mathrm{mm} / \mathrm{hari})$,

ER = hujan efektif ( $\mathrm{mm} /$ hari),

IE = efisiensi irigasi (-),

A $=$ luas areal irigasi $\left(\mathrm{m}^{2}\right)$.

Neraca Sumber Daya Air

Neraca sumber daya air merupakan selisih antara ketersediaan air dengan aliran yang keluar pada suatu sistem tertentu (Harto, 2000).

Neraca $=Q$ Ketersediaan $-Q$ Kebutuhan

dimana:

Neraca $\quad=$ Neraca sumber daya air (surplus jika hasil persamaan adalah positif dan defisit apabila hasil persamaan adalah negatif)

Q ketersediaan= Debit ketersediaan air,

Q kebutuhan= Debit kebutuhan air.

\section{Peta Neraca Sumber Daya Air}

Peta neraca sumber daya air adalah peta dengan informasi yang disajikan berupa imbangan potensi, ketersediaan dan penggunaan daya air dalam kurun waktu bulanan maupun tahunan (SNI 6728.1:2015).

\section{METODE PENELITIAN}

Metode yang digunakan pada penelitian ini adalah deskriptif kuantitatif. Penelitian ini diawali dengan membuat peta kerja, menghitung debit ketersediaan air dengan simulasi hujan-debit menggunakan metode Mock 15 harian, menghitungan kebutuhan air, menghitung neraca sumber daya air dan membuat peta neraca sumber daya air.

Lokasi penelitian di DAS Ngunggahan Wonogiri dengan memanfaatkan data sekunder, yaitu :

a. Informasi geospasial dasar Kabupaten Wonogiri skala 1:25.000 dari Ina-Geoportal,

b. Peta daerah aliran sungai (DAS) Ngunggahan skala 1:25.000 dari Balai Besar Wilayah Sungai (BBWS) Bengawan Solo, 
c. Lokasi stasiun hujan dan iklim di area DAS Ngunggahan dari DPUPR Kabupaten Wonogiri,

d. Peta lokasi bangunan-bangunan air dari Ina-Geoportal,

e. Data curah harian tahun 2008-2017 stasiun hujan Eromoko, Kedunguling dan Wuryantoro dari DPUPR

Kabupaten Wonogiri,

f. Data klimatologi 2008-2017 dari Balai PUSDATARU Bengawan Solo,

g. Peta tata guna lahan DAS Ngunggahan dari Ina-Geoportal,

h. Data demografi Kabupaten Wonogiri dari BPS Wonogiri,

i. Data peternakan dan perikanan Kabupaten Wonogiri dari BPS Wonogiri,

j. Data perindustrian Kabupaten Wonogiri dari BPS Wonogiri,

k. Data irigasi yang meliputi data pola tanam pertanian dan luas daerah irigasi dari citra satelit google earth, DPUPR Kabupaten Wonogiri dan Kementrian Pertanian Indonesia.

Software yang digunakan untuk membantu analisis adalah :

a. Microsoft Excel untuk proses perhitungan ketersediaan air, kebutuhan air dan neraca air,

b. Cropwat untuk menghitung nilai evapotransipirasi,

c. Minitab untuk menghitung prediksi curah hujan tahun 2018 dan 2019,

d. ArGGIS untuk pengolahan peta.

\section{HASIL DAN PEMBAHASAN}

\section{Pembuatan Peta Kerja}

Informasi geospasial dasar Kabupaten Wonogiri didapatkan dari website ina-geoportal. Data tersebut berupa batas administrasi, kontur, transportasi, sungai dan tutupan lahan dengan ekstensi (.shp). Peta kerja dibuat menggunakan software ArcGIS dengan mengolah shapefile Kabupaten Wonogiri dengan data lain, yaitu berupa batas DAS Ngunggahan, informasi lokasi bangunan air serta informasi koordinat stasiun hujan dan iklim. Analisis neraca sumber daya air pada DAS Ngunggahan akan dilakukan dengan membagi DAS, menjadi beberapa Sub DAS. Hal ini disebabkan DAS Ngunggahan memiliki 2 outlet dibagian hilirnya. Karena luas wilayah yang tidak terlalu besar, maka DAS Ngunggahan ini akan dibagi menjadi 3 Sub DAS.

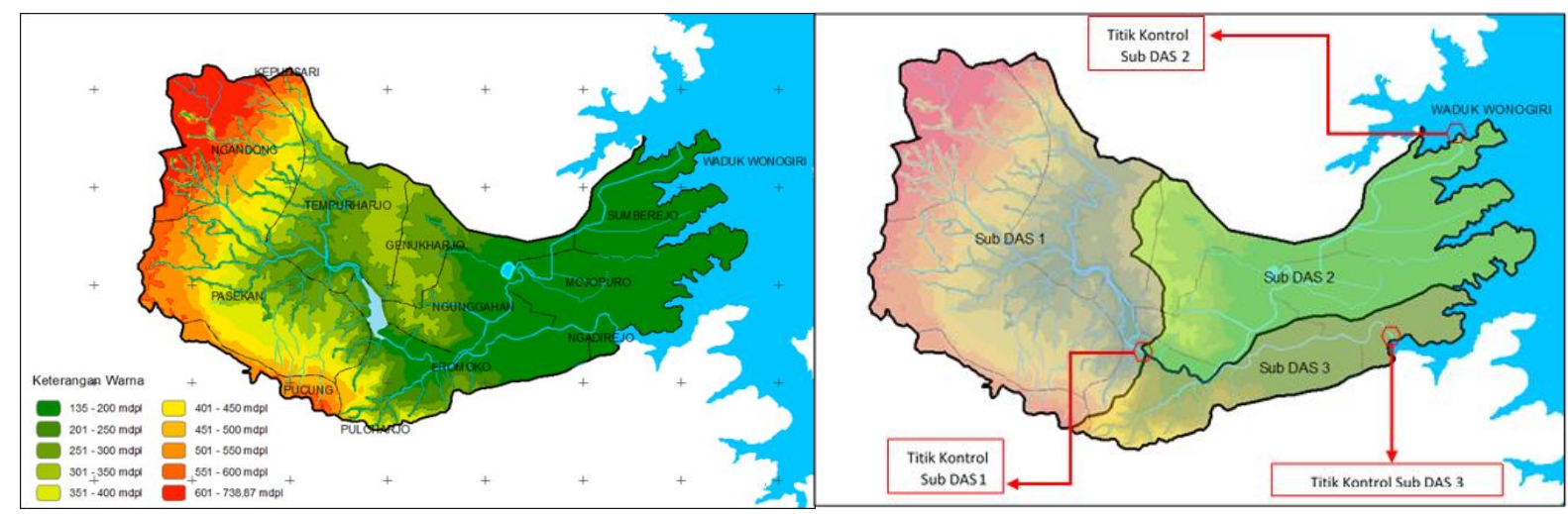

Gambar 1 Peta Digital Elevating Model (DEM) (kiri) dan Peta Pembagian Sub DAS Ngunggahan (kanan)

\section{Ketersediaan Air}

Perhitungan ketersediaan air dimulai dengan mengubah data hujan harian menjadi 15 harian. Setelah itu menghitung hujan wilayah menggunakan metode Polygon Thiessen dilanjutkan memprediksi hujan tahun 2018 dan 2019 menggunakan metode SARIMA (Seasonal Autoregressive Integrated Moving Average).

Data debit lapangan tidak ditemukan sehinga perlu melakukan simulasi hujan-debit metode Mock 15 harian. Perhitungan Mock pada DAS Ngunggahan menggunakan beberapa parameter data, diantaranya $C A=26,58 \mathrm{~km}^{2}$, $\mathrm{SMC}=150 \mathrm{~mm}, \mathrm{k}=0,15$ dan $\mathrm{i}=0,85$. Berikut contoh hasil perhitungan pada Sub DAS 1 bulan Januari ke-2. Pertama, menghitung nilai evapotranspirasi terbatas (ET), didapatkan sebesar $52,48 \mathrm{~mm}$. Selanjutnya water balance yang didapatkan dari perhitungan sebesar $0 \mathrm{~mm} / \mathrm{bln}$. Run off dari perhitungan sebesar 19,63 mm. Tahap terakhir simulasi Mock didapatkan nilai effective discharge pada bulan Januari ke-2 sebesar 380 liter/dt.

Hasil dari simulasi Mock adalah debit dengan runtut waktu sebanyak jumlah tahun pada data. Debit yang dipakai sebagai debit ketersediaan tahun 2019 adalah debit yang memiliki keandalan 80\% (Q80). Debit dengan probabilitas 80\% dihitung dengan menggunakan metode Basic Month dan Weibull. Hasil perhitungan Q80 pada semua Sub DAS dapat dilihat pada tabel 2 dan 3 sebagai Qin. 


\section{Kebutuhan Air}

Kebutuhan air yang dihitung meliputi kebutuhan air pemeliharaan sungai, kebutuhan air RKI (rumah tangga, perkotaan dan industri), kebutuhan air perikanan, kebutuhan air peternakan dan kebutuhan air irigasi. Perhitungan kebutuhan air tersebut menggunakan persamaan yang ada pada SNI 6728.1:2015. Contoh hasil perhitungan kebutuhan air pada Sub DAS 1 akan disajikan pada tabel 1.

Tabel 1 Hasil Perhitungan Kebutuhan Air pada Sub DAS 1 Tahun 2019

\begin{tabular}{|c|c|c|c|c|c|c|c|}
\hline \multirow{2}{*}{\multicolumn{2}{|c|}{ Periode }} & \multicolumn{5}{|c|}{ Sub DAS 1 (Liter/dt) } & \multirow{2}{*}{ Total } \\
\hline & & $Q_{\text {pemeliharaan }}$ & QRKI & $Q_{\text {perikanan }}$ & $Q_{\text {peternakan }}$ & $Q_{\text {irigasi }}$ & \\
\hline \multirow{2}{*}{ Jan } & I & 148 & 95 & 0 & 21 & 605 & 869 \\
\hline & II & 0 & 102 & 0 & 23 & 1523 & 1647 \\
\hline \multirow{2}{*}{ Feb } & $\mathrm{I}$ & 766 & 95 & 0 & 21 & 1190 & 2072 \\
\hline & II & 330 & 83 & 0 & 18 & 0 & 431 \\
\hline \multirow{2}{*}{ Mar } & $\mathrm{I}$ & 0 & 95 & 0 & 21 & 93 & 210 \\
\hline & II & 0 & 102 & 0 & 23 & 208 & 333 \\
\hline \multirow{2}{*}{ Apr } & $\mathrm{I}$ & 0 & 95 & 0 & 21 & 208 & 324 \\
\hline & II & 328 & 95 & 0 & 21 & 243 & 687 \\
\hline \multirow{2}{*}{ Mei } & $\mathrm{I}$ & 0 & 95 & 0 & 21 & 270 & 387 \\
\hline & II & 0 & 102 & 0 & 23 & 0 & 124 \\
\hline \multirow{2}{*}{ Jun } & I & 0 & 95 & 0 & 21 & 0 & 116 \\
\hline & II & 0 & 95 & 0 & 21 & 0 & 116 \\
\hline \multirow{2}{*}{ Jul } & $\mathrm{I}$ & 0 & 95 & 0 & 21 & 0 & 116 \\
\hline & II & 0 & 102 & 0 & 23 & 0 & 124 \\
\hline \multirow{2}{*}{ Ags } & I & 0 & 95 & 0 & 21 & 0 & 116 \\
\hline & II & 0 & 102 & 0 & 23 & 0 & 124 \\
\hline \multirow{2}{*}{ Sep } & $\mathrm{I}$ & 0 & 95 & 0 & 21 & 0 & 116 \\
\hline & II & 0 & 95 & 0 & 21 & 985 & 1101 \\
\hline \multirow{2}{*}{ Okt } & $\mathrm{I}$ & 0 & 95 & 0 & 21 & 1980 & 2096 \\
\hline & II & 0 & 102 & 0 & 23 & 1899 & 2024 \\
\hline \multirow{2}{*}{ Nop } & I & 156 & 95 & 0 & 21 & 1237 & 1510 \\
\hline & II & 0 & 95 & 0 & 21 & 1013 & 1129 \\
\hline \multirow{2}{*}{ Des } & $\mathrm{I}$ & 0 & 95 & 0 & 21 & 1047 & 1164 \\
\hline & II & 2 & 102 & 0 & 23 & 995 & 1121 \\
\hline \multicolumn{2}{|c|}{ Jumlah } & 1729 & 2317 & 0 & 517 & 13497 & 18060 \\
\hline
\end{tabular}

Selanjutnya total hasil perhitungan kebutuhan air pada ke-3 Sub DAS dapat dilihat pada tabel 2 dan 3 sebagai Qout.

\section{Neraca Sumber Daya Air}

Perhitungan neraca sumber daya air didasarkan pada analisis keseimbangan ketersediaan air sungai dan kebutuhan air di DAS Ngunggahan. Contoh skema aliran sungai dan pembagian air di DAS Ngunggahan dapat dilihat pada gambar 2.

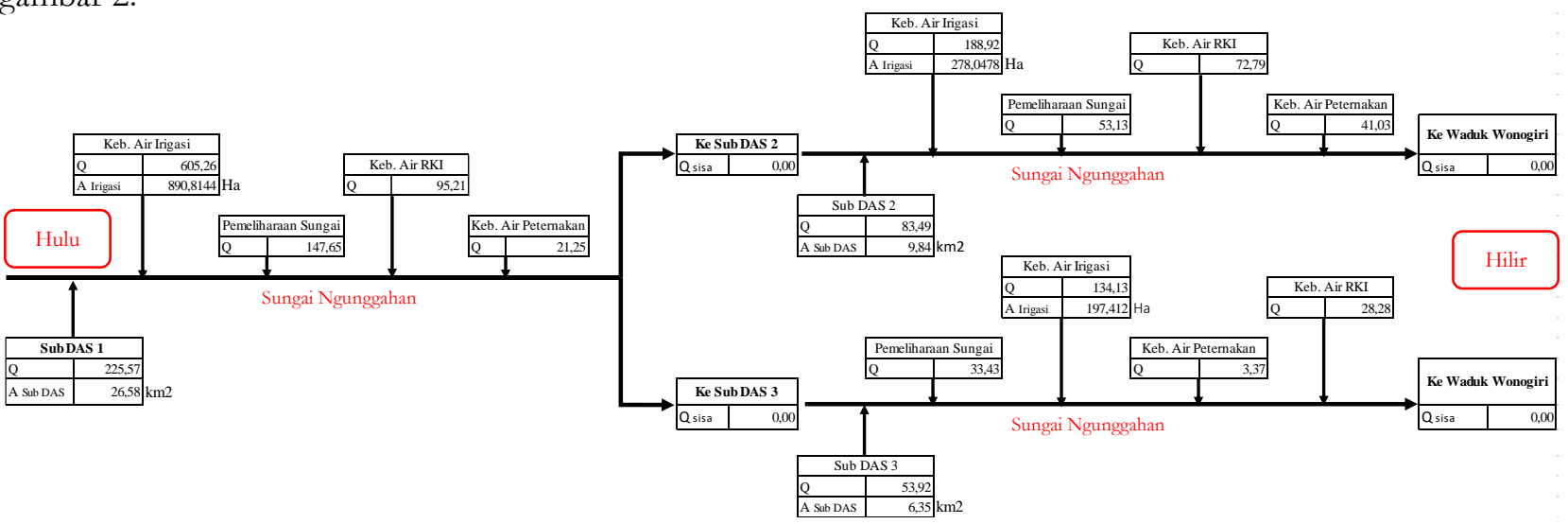

Gambar 2 Contoh Skema Neraca Sumber Daya Air Bulan Januari ke I pada DAS Ngunggahan 
Terdapat 2 waduk didalam DAS Ngunggahan, yaitu waduk Parangjoho di Sub DAS 1 dan waduk Kedunguling di Sub DAS 2. Dalam analisis, debit dari kedua waduk tersebut tidak diperhitungkan, sehingga neraca sumber daya air dibagi menjadi dua. Yaitu neraca sumber daya air dengan asumsi semua kebutuhan air dipenuhi dari debit perhitungan (sungai) dan neraca sumber daya air dengan asumsi kebutuhan air irigasi sudah dipenuhi dari waduk Parangjoho dan Kedunguling.

Tabel 2 Neraca Sumber Daya Air Tahun 2019 dengan Asumsi Semua Kebutuhan Air Dipenuhi dari Sungai

\begin{tabular}{|c|c|c|c|c|c|c|c|c|c|c|}
\hline \multirow{2}{*}{\multicolumn{2}{|c|}{ Periode }} & \multicolumn{3}{|c|}{ Sub DAS 1 (Liter/dt) } & \multicolumn{3}{|c|}{ Sub DAS 2 (Liter/dt) } & \multicolumn{3}{|c|}{ Sub DAS 3 (Liter/dt) } \\
\hline & & Qin & Qout & Saldo & Qin & Qout & Saldo & Qin & Qout & Saldo \\
\hline \multirow{2}{*}{ Jan } & I & 226 & 869 & -644 & 83 & 356 & -272 & 54 & 199 & -145 \\
\hline & II & 904 & 1647 & -744 & 334 & 438 & -104 & 216 & 371 & -155 \\
\hline \multirow{2}{*}{ Feb } & I & 1333 & 2072 & -739 & 493 & 771 & -278 & 319 & 467 & -148 \\
\hline & II & 592 & 431 & 161 & 299 & 561 & -261 & 222 & 101 & 121 \\
\hline \multirow{2}{*}{ Mar } & I & 46 & 210 & -164 & 22 & 521 & -500 & 14 & 52 & -38 \\
\hline & II & 85 & 333 & -247 & 34 & 400 & -366 & 22 & 80 & -58 \\
\hline \multirow{2}{*}{ Apr } & I & 625 & 324 & 301 & 378 & 438 & -60 & 298 & 78 & 220 \\
\hline & II & 0 & 687 & -687 & 0 & 543 & -543 & 0 & 164 & -164 \\
\hline \multirow{2}{*}{ Mei } & $\mathrm{I}$ & 0 & 387 & -387 & 0 & 360 & -360 & 0 & 92 & -92 \\
\hline & II & 0 & 124 & -124 & 0 & 194 & -194 & 0 & 34 & -34 \\
\hline \multirow{2}{*}{ Jun } & $\mathrm{I}$ & 0 & 116 & -116 & 0 & 112 & -112 & 0 & 32 & -32 \\
\hline & II & 0 & 116 & -116 & 0 & 112 & -112 & 0 & 32 & -32 \\
\hline \multirow{2}{*}{ Jul } & $\mathrm{I}$ & 0 & 116 & -116 & 0 & 112 & -112 & 0 & 32 & -32 \\
\hline & II & 0 & 124 & -124 & 0 & 120 & -120 & 0 & 34 & -34 \\
\hline \multirow{2}{*}{ Ags } & I & 0 & 116 & -116 & 0 & 112 & -112 & 0 & 32 & -32 \\
\hline & II & 0 & 124 & -124 & 0 & 120 & -120 & 0 & 34 & -34 \\
\hline \multirow{2}{*}{ Sep } & I & 0 & 116 & -116 & 0 & 112 & -112 & 0 & 32 & -32 \\
\hline & II & 0 & 1101 & -1101 & 0 & 420 & -420 & 0 & 250 & -250 \\
\hline \multirow{2}{*}{ Okt } & I & 0 & 2096 & -2096 & 0 & 730 & -730 & 0 & 470 & -470 \\
\hline & II & 0 & 2024 & -2024 & 0 & 712 & -712 & 0 & 455 & -455 \\
\hline \multirow{2}{*}{ Nop } & I & 349 & 1510 & -1161 & 129 & 576 & -447 & 83 & 356 & -273 \\
\hline & II & 349 & 1129 & -781 & 129 & 428 & -299 & 83 & 256 & -173 \\
\hline \multirow{2}{*}{ Des } & I & 235 & 1164 & -929 & 107 & 439 & -332 & 69 & 264 & -195 \\
\hline & II & 71 & 1121 & -1050 & 23 & 434 & -411 & 15 & 257 & -242 \\
\hline \multicolumn{2}{|c|}{ Total } & 4813 & 18060 & -13247 & 2032 & 9123 & -7091 & 1394 & 4171 & -2777 \\
\hline
\end{tabular}

Tabel 2 menunjukkan neraca sumber daya air dengan asumsi semua kebutuhan air dipenuhi dari sungai. Pada Sub DAS 1 surplus air terjadi pada bulan Februari ke II, yaitu 161 liter/dt dan April ke I sebesar 301 liter/dt. Pada Sub DAS 2 tidak terdapat surplus sama sekali. Pada Sub DAS 3 surplus air terjadi pada bulan Februari ke II, yaitu 121 liter/dt dan April ke I yaitu 220 liter/dt.

Grafik ketersediaan dan kebutuhan air tengah bulanan tahun 2019 dengan asumsi semua kebutuhan air dipenuhi dari sungai disajikan pada gambar 3, 4 dan 5 .

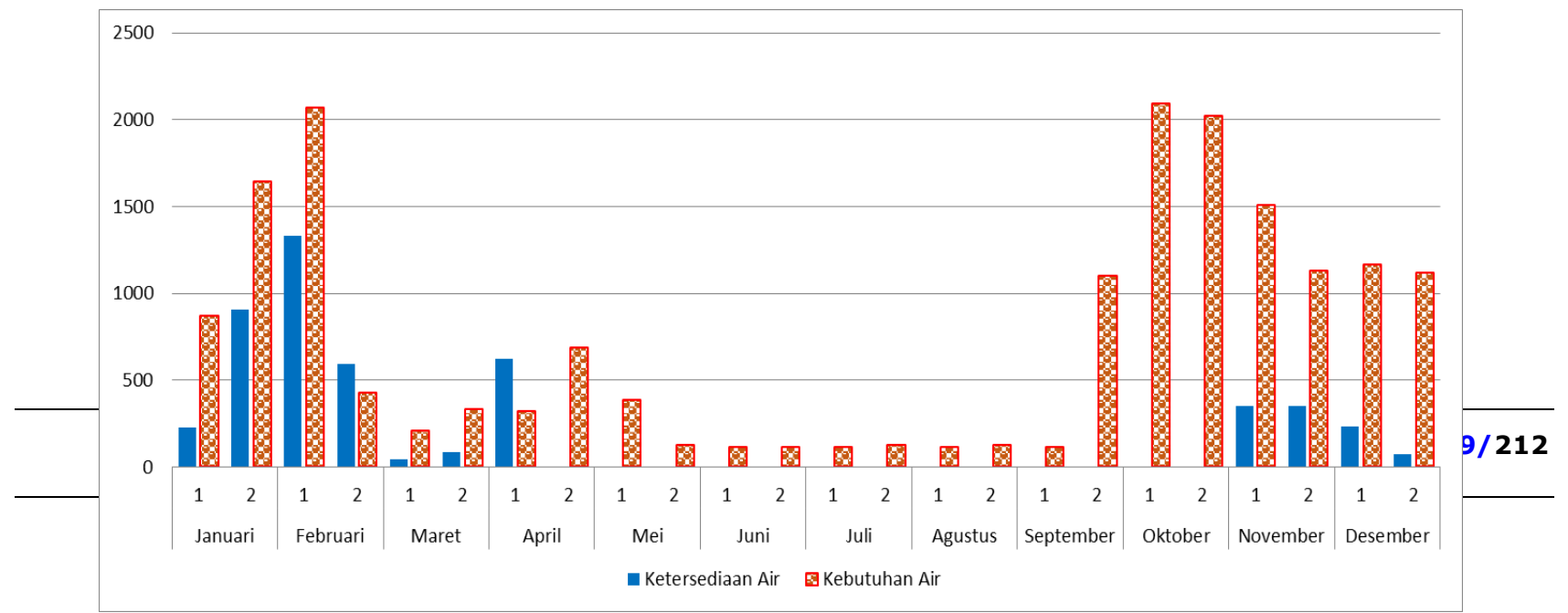


Gambar 3 Grafik Ketersediaan dan Kebutuhan Air dengan Asumsi Semua Kebutuhan Air Dipenuhi dari Sungai pada Sub DAS 1

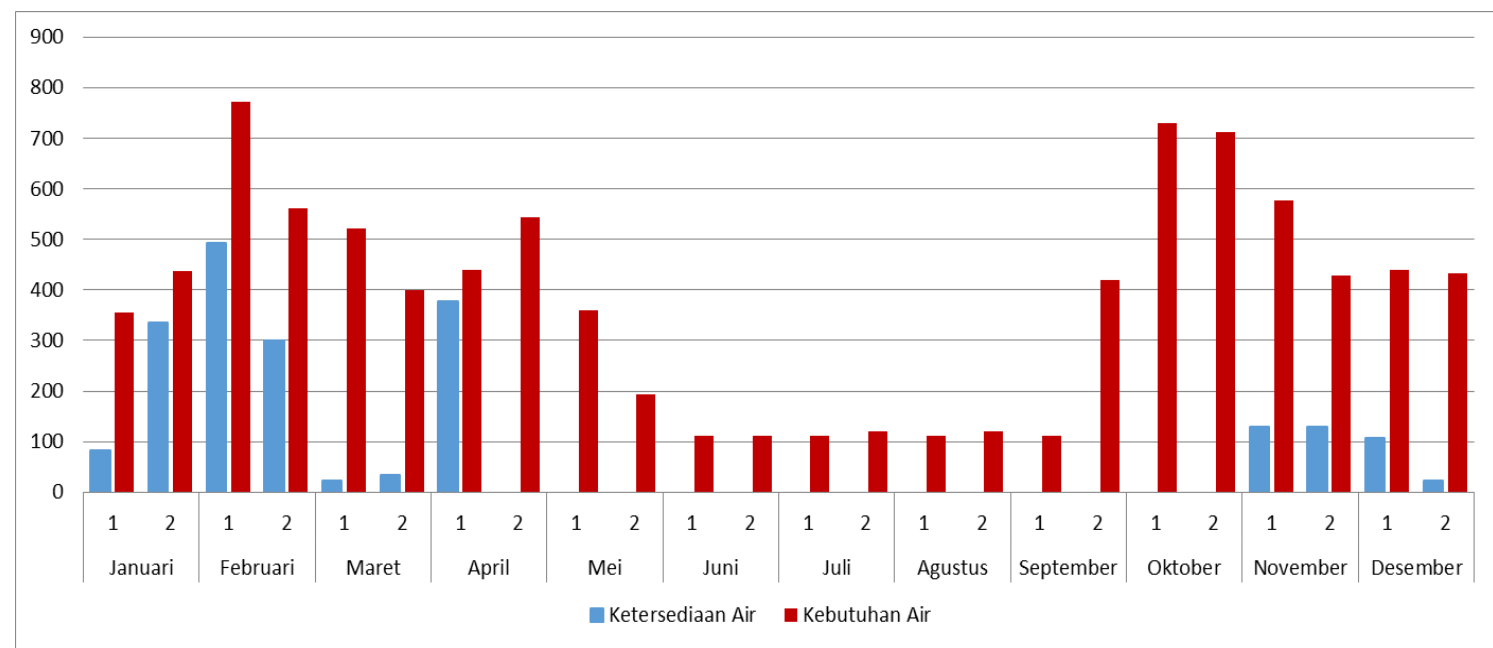

Gambar 4 Grafik Ketersediaan dan Kebutuhan Air dengan Asumsi Semua Kebutuhan Air Dipenuhi dari Sungai pada Sub DAS 2

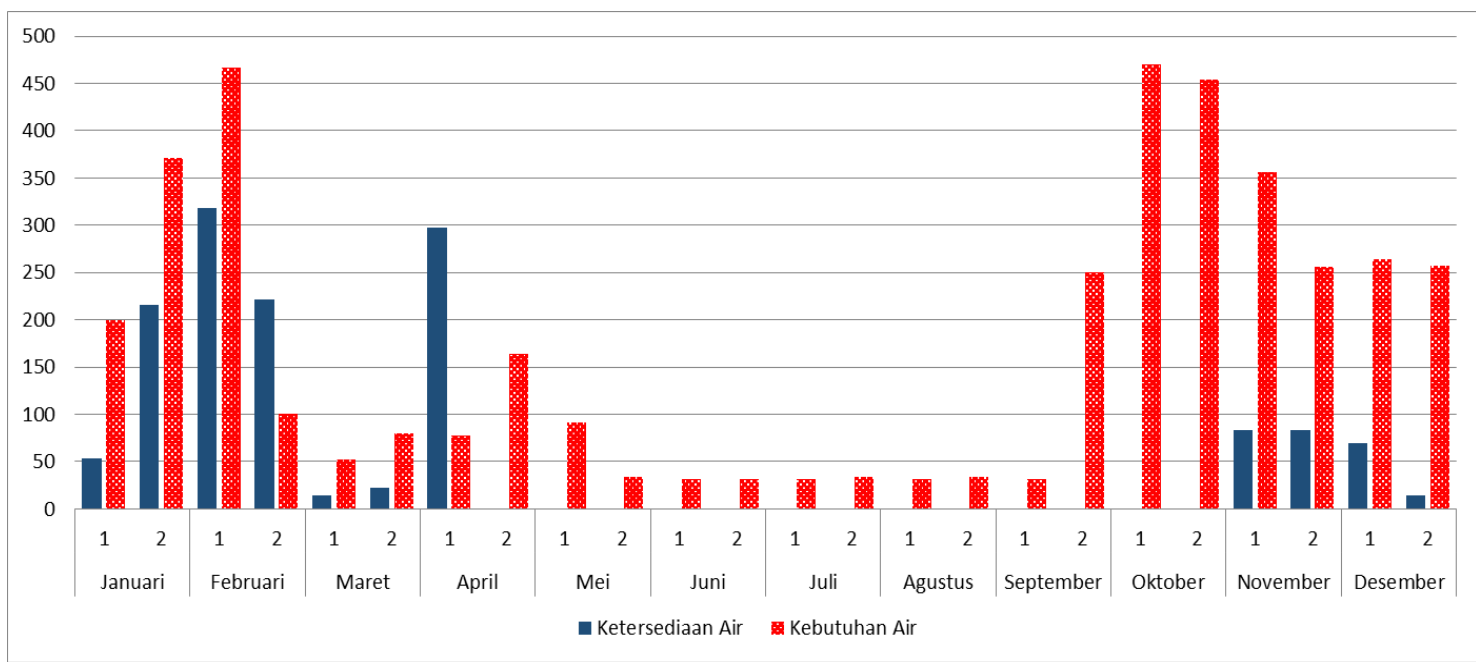

Gambar 5 Grafik Ketersediaan dan Kebutuhan Air dengan Asumsi Semua Kebutuhan Air Dipenuhi dari Sungai pada Sub DAS 3

Neraca dengan asumsi kebutuhan air irigasi sudah dipenuhi dari waduk dapat dilihat pada Tabel 3.

Tabel 3 Neraca Sumber Daya Air Tahun 2019 dengan Asumsi Kebutuhan Air Irigasi Dipenuhi dari Waduk

\begin{tabular}{|c|c|c|c|c|c|c|c|c|c|c|}
\hline \multirow{2}{*}{\multicolumn{2}{|c|}{ Periode }} & \multicolumn{3}{|c|}{ Sub DAS 1 (Liter/dt) } & \multicolumn{3}{|c|}{ Sub DAS 2 (Liter/dt) } & \multicolumn{3}{|c|}{ Sub DAS 3 (Liter/dt) } \\
\hline & & $Q^{i n}$ & Qout & Saldo & Qin & Qout & Saldo & Qin & Qout & Saldo \\
\hline \multirow{2}{*}{ Jan } & I & 226 & 264 & -39 & 83 & 167 & -83 & 54 & 65 & -11 \\
\hline & II & 904 & 124 & 779 & 724 & 120 & 605 & 606 & 34 & 572 \\
\hline \multirow{2}{*}{ Feb } & $\mathrm{I}$ & 1333 & 883 & 450 & 718 & 378 & 341 & 544 & 203 & 341 \\
\hline & II & 592 & 431 & 161 & 299 & 212 & 88 & 222 & 101 & 121 \\
\hline
\end{tabular}




\begin{tabular}{|c|c|c|c|c|c|c|c|c|c|c|}
\hline \multirow{2}{*}{ Mar } & $\mathrm{I}$ & 46 & 116 & -71 & 22 & 112 & -91 & 14 & 32 & -18 \\
\hline & II & 85 & 124 & -39 & 34 & 120 & -86 & 22 & 34 & -12 \\
\hline \multirow{2}{*}{ Apr } & $\mathrm{I}$ & 625 & 116 & 509 & 482 & 112 & 370 & 401 & 32 & 370 \\
\hline & II & 0 & 445 & -445 & 0 & 234 & -234 & 0 & 110 & -110 \\
\hline \multirow{2}{*}{ Mei } & I & 0 & 116 & -116 & 0 & 112 & -112 & 0 & 32 & -32 \\
\hline & II & 0 & 124 & -124 & 0 & 120 & -120 & 0 & 34 & -34 \\
\hline \multirow{2}{*}{\multicolumn{2}{|c|}{$\begin{array}{c}\text { I } \\
\text { Lanjuntan Tạbel } 3\end{array}$}} & 0 & 116 & -116 & 0 & 112 & -112 & 0 & 32 & -32 \\
\hline & & 0 & 116 & -116 & 0 & 112 & -112 & 0 & 32 & -32 \\
\hline \multirow{2}{*}{ Jul } & $\mathrm{I}$ & 0 & 116 & -116 & 0 & 112 & -112 & 0 & 32 & -32 \\
\hline & II & 0 & 124 & -124 & 0 & 120 & -120 & 0 & 34 & -34 \\
\hline \multirow{2}{*}{ Ags } & I & 0 & 116 & -116 & 0 & 112 & -112 & 0 & 32 & -32 \\
\hline & II & 0 & 124 & -124 & 0 & 120 & -120 & 0 & 34 & -34 \\
\hline \multirow{2}{*}{ Sep } & I & 0 & 116 & -116 & 0 & 112 & -112 & 0 & 32 & -32 \\
\hline & II & 0 & 116 & -116 & 0 & 112 & -112 & 0 & 32 & -32 \\
\hline \multirow{2}{*}{ Okt } & I & 0 & 116 & -116 & 0 & 112 & -112 & 0 & 32 & -32 \\
\hline & II & 0 & 124 & -124 & 0 & 120 & -120 & 0 & 34 & -34 \\
\hline \multirow{2}{*}{ Nop } & I & 349 & 272 & 76 & 167 & 190 & -23 & 121 & 82 & 40 \\
\hline & II & 349 & 116 & 232 & 245 & 112 & 133 & 199 & 32 & 168 \\
\hline \multirow{2}{*}{ Des } & $\mathrm{I}$ & 235 & 116 & 118 & 166 & 112 & 54 & 128 & 32 & 97 \\
\hline & II & 71 & 126 & -55 & 23 & 123 & -100 & 15 & 36 & -21 \\
\hline \multicolumn{2}{|c|}{ Total } & 4813 & 4563 & 250 & 2964 & 3368 & -404 & 2326 & 1180 & 1146 \\
\hline
\end{tabular}

Tabel 3 merupakan neraca sumber daya air dengan asumsi kebutuhan air irigasi dipenuhi dari waduk. Pada Sub DAS 1 surplus air terjadi pada bulan Januari ke II, Februari ke I \& II, April ke I, November ke I \& II, serta Desember ke I. Pada Sub DAS 2 surplus air terjadi pada bulan Januari ke II, Februari ke I \& II, April ke I, November ke II, dan Desember ke I. Pada Sub DAS 3 surplus air terjadi pada bulan Januari ke II, Februari ke I \& II, April ke I, November ke I \& II, serta Desember ke I.

Grafik ketersediaan dan kebutuhan air tengah bulanan tahun 2019 dengan asumsi kebutuhan air irigasi dipenuhi dari waduk disajikan pada gambar 6, 7 dan 8.

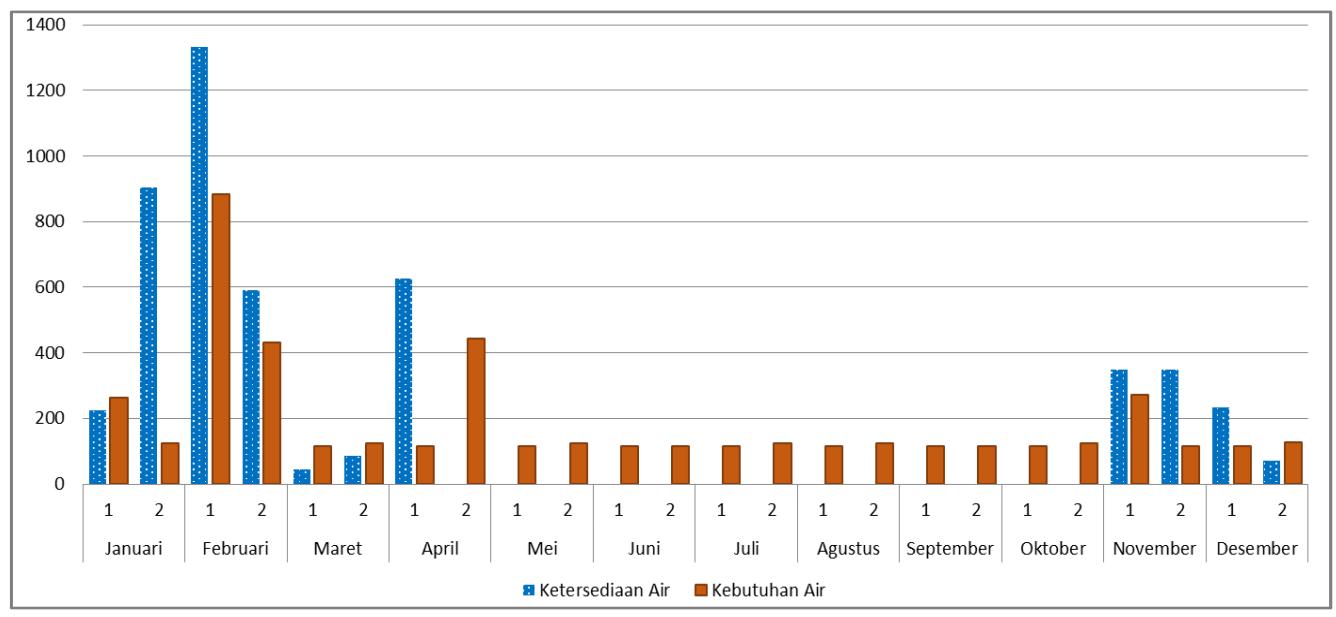

Gambar 6 Grafik Ketersediaan dan Kebutuhan Air dengan Asumsi Kebutuhan Air Irigasi Dipenuhi dari Waduk pada Sub DAS 1

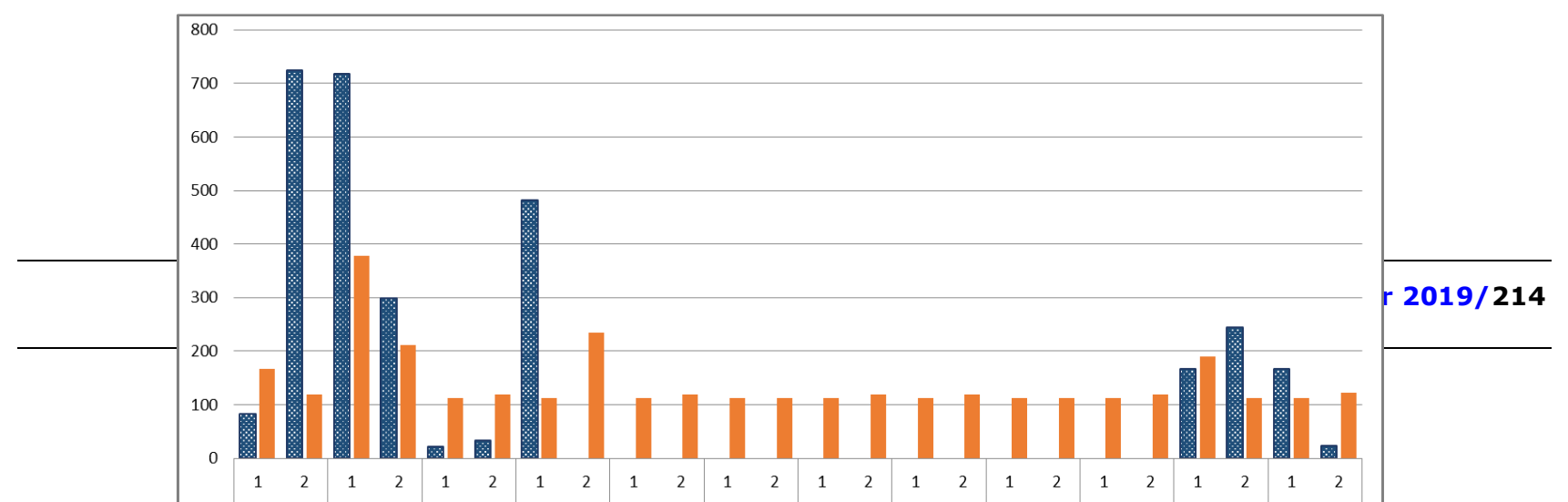


Gambar 7 Grafik Ketersediaan dan Kebutuhan Air dengan Asumsi Kebutuhan Air Irigasi Dipenuhi dari Waduk pada Sub DAS 2

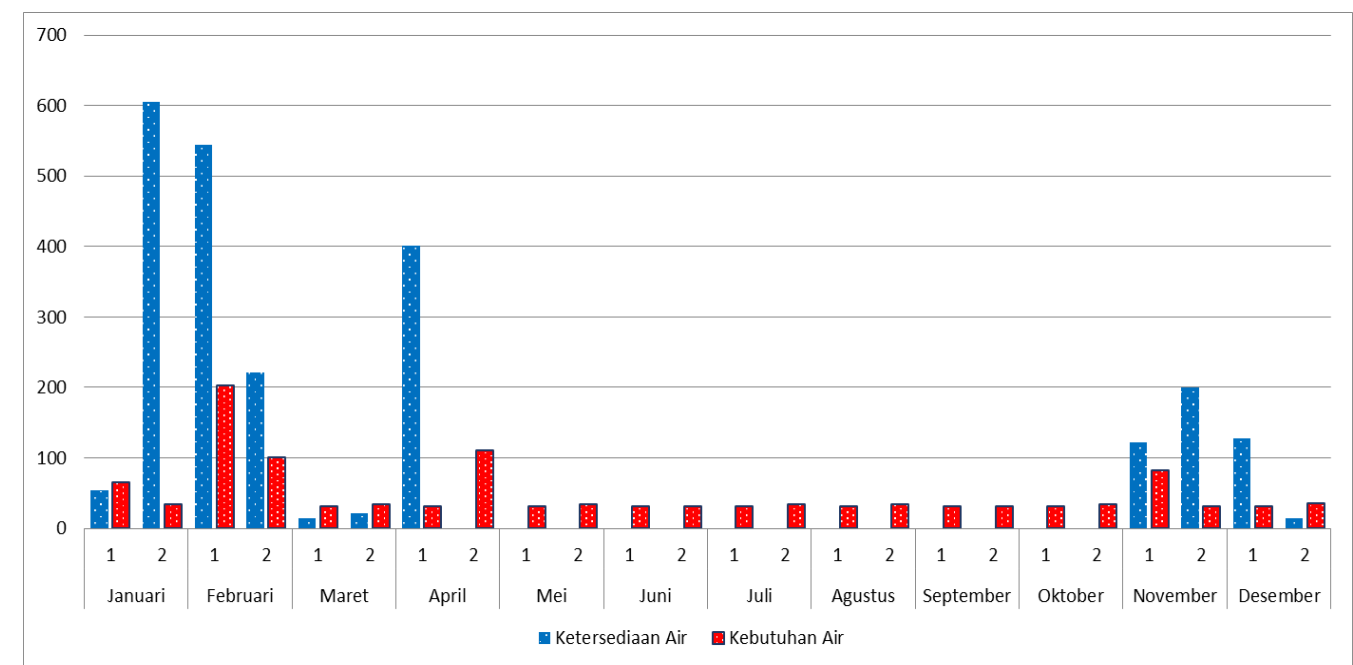

Gambar 8 Grafik Ketersediaan dan Kebutuhan Air dengan Asumsi Kebutuhan Air Irigasi Dipenuhi dari Waduk pada Sub DAS 3

\section{Peta Neraca Sumber Daya Air}

Pemetaan dilakukan menggunakan bantuan software AroGIS. Notasi warna didasarkan pada SNI 6729.1:2015 tentang neraca sumber daya air. Beberapa ketentuan notasi warna adalah sebagai berikut :

Merah $=<0 \mathrm{~m}^{3} /$ tahun

Oranye $\quad=0-100 \times 10^{6} \mathrm{~m}^{3} /$ tahun

Kuning $=101 \times 10^{6}-500 \times 10^{6} \mathrm{~m}^{3} /$ tahun

Hijau $=501 \times 10^{6}-1000 \times 10^{6} \mathrm{~m}^{3} /$ tahun

Biru Muda $=1001 \times 10^{6}-1500 \times 10^{6} \mathrm{~m}^{3} /$ tahun

Biru Tua $=>1500 \times 10^{6} \mathrm{~m}^{3} /$ tahun.

Tabel 4 Rekapitulasi Neraca Sumber Daya Air Tahunan pada DAS Ngunggahan Tahun 2019

Asumsi Semua Kebutuhan Air

Dipenuhi dari Sungai
Asumsi Kebutuhan Irigasi Dipenuhi dari Waduk

\begin{tabular}{ccccc}
\hline & Saldo $\left(10^{6} \mathrm{~m}^{3} /\right.$ tahun $)$ & Warna & Saldo $\left(10^{6} \mathrm{~m}^{3} /\right.$ tahun $)$ & Warna \\
\hline Sub DAS 1 & 0,0000 & Merah & 7,8764 & Oranye \\
\hline Sub DAS 2 & 0,0000 & Merah & 0,0000 & Merah \\
\hline Sub DAS 3 & 0,0000 & Merah & 36,1546 & Oranye \\
\hline
\end{tabular}

Neraca dengan asumsi semua kebutuhan air dipenuhi dari sungai, pada semua Sub DAS tidak terdapat saldo air (defisit), sehingga notasi warna pada peta adalah merah. Sedangkan jika asumsi kebutuhan air untuk irigasi sudah dipenuhi dari waduk terdapat surplus air pada Sub DAS 1 sebesar 7,8764 m³/tahun dan pada Sub DAS 3 sebesar 
36,1546 $\mathrm{m}^{3} /$ tahun, sehingga notasi warna pada Sub DAS 1 dan 3 berwarna oranye dan Sub DAS 2 berwarna merah karena tidak terdapat saldo air.

Peta neraca sumber daya air tahunan pada DAS Ngunggahan tahun 2019 menggunakan ArcGIS dapat dilihat pada gambar 9 dan 10.

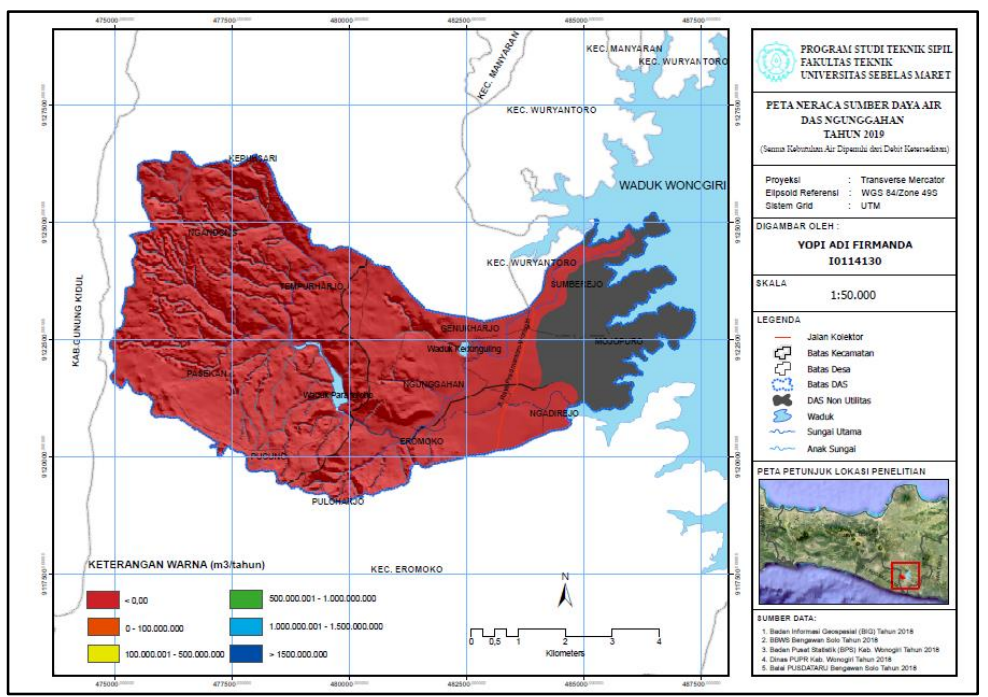

Gambar 9 Peta Neraca Sumber Daya Air DAS Ngunggahan Tahun 2019 dengan Asumsi Semua Kebutuhan Air Dipenuhi dari Debit Perhitungan (Sungai)

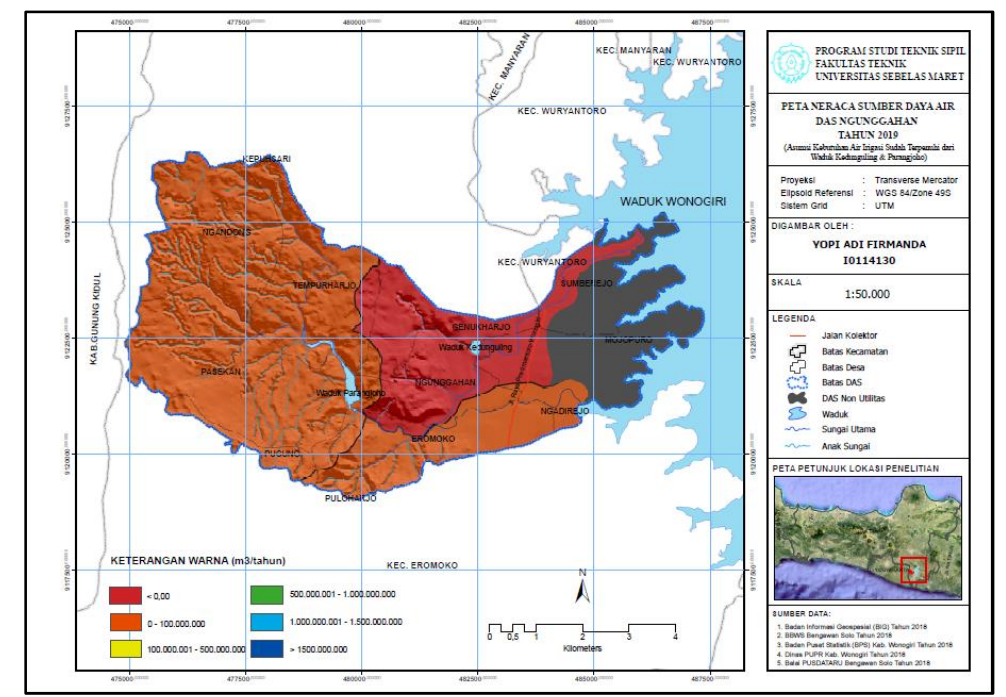

Gambar 10 Peta Neraca Sumber Daya Air DAS Ngunggahan Tahun 2019 dengan Asumsi Kebutuhan Air Irigasi Dipenuhi dari Waduk

\section{SIMPULAN}

Berdasarkan pada analisis dan pembahasan dapat di ambil kesimpulan sebagai berikut:

1. Potensi ketersediaan air pada ketiga Sub DAS paling melimpah terjadi pada bulan Februari periode ke 1, yaitu 1332,94 liter/dt pada Sub DAS 1, 493,34 liter/dt pada Sub DAS 2 dan 318,60 liter/dt pada Sub DAS 3. Secara keseluruhan pada tahun 2019, Sub DAS 1 memiliki ketersediaan air sebesar 1517,788 x $10^{8}$ liter/tahun, Sub DAS 2 memiliki ketersediaan air 640,887 x $10^{8}$ liter/tahun dan 439,689 x $10^{8}$ liter/ tahun untuk Sub DAS 3.

2. Mempertimbangan semua kebutuhan air, tingkat kebutuhan air terbesar Sub DAS 1 terjadi pada bulan Oktober periode ke 1 yaitu 2096,12 liter/dt. Pada Sub DAS 2 terjadi pada bulan Februari periode 1 yaitu sebesar 771,36 liter/dt. Pada Sub DAS 3 terjadi pada Oktober periode 1 yaitu sebesar 470,36 liter/dt. Secara keseluruhan pada tahun 2019, tingkat kebutuhan air pada Sub DAS 1 adalah 5695,451 x $10^{8}$ liter/tahun, pada Sub DAS 2 sebesar $2876,95 \times 10^{8}$ liter/ tahun dan 1315,31 x $10^{8}$ liter/ tahun pada Sub DAS 3. Sub DAS 1 memiliki kebutuhan air paling besar karena luas wilayahnya paling besar dibanding ke dua Sub DAS lainnya. 
3. Secara keseluruhan tahun 2019 dengan mempertimbangkan semua kebutuhan air, peta neraca tahunan DAS Ngunggahan berwarna merah yang berarti tidak terdapat surplus pada setiap Sub DASnya. Sedangkan dengan asumsi jika kebutuhan air irigasi sudah dipenuhi dari waduk, maka pada tahun 2019 Sub DAS 1 berwarna oranye karena terdapat surplus sebesar 78,76 x $10^{8}$ liter/tahun dan pada Sub DAS 3 juga berwarna oranye dengan surplus sebesar 361,55 × $10^{8}$ liter/tahun. Sedangkan pada Sub DAS 2 defisit air, sehingga berwarna merah.

\section{REKOMENDASI}

1. Prediksi pola tanam sangat mempengaruhi keseimbangan air yang didapatkan, sehingga penetuan prediksi pola tanam perlu diperhatikan agar tidak terjadi defisit air yang berlebihan.

2. Melihat bahwa ketersediaan air di DAS Ngunggahan tersebut kurang, maka membuat Sistem Pemanen Air Hujan (SPAH) tiap rumah atau sawah sangat disarankan dalam rangka penghematan air.

3. Dalam penelitian ini tidak memperhitungkan air tanah dan air dari bendungan/waduk, namun menghitung kebutuhan air secara detail, sehingga didapatkan selisih antara kebutuhan dan ketersediaan air yang cukup jauh. Penelitian selanjutnya hendaknya mempertimbangkan air dari tanah dan juga air dari bendungan/waduk.

\section{UCAPAN TERIMAKASIH}

Penulis bersyukur kepada Allah SWT atas segala nikmat dan ridho-Nya sebagai jalan kemudahan dalam menyelesaikan penelitian ini. Ucapan terimakasih kepada Dr. Ir. Rr. Rintis Hadiani, M.T. dan Ir. Agus Prijadi Saido, M.Sc selaku dosen pembimbing yang selalu sabar memberikan arahan serta masukan dalam pelaksanaan penelitian ini.

\section{REFERENSI}

Andreas Ricky Dipra Mahendra. 2013. Analisis Neraca Air Daerah Aliran Sungai Ngunggahan Sub DAS Bengawan Solo Hulu 3. Tugas Akhir. Fakultas Teknik. Universitas Sebelas Maret Surakarta.

Ary Miftakul Huda, Achmad Choiruddin, Osaliana Budiarto dan Sutikno. 2012. Peramalan Data Curah Hujan dengan Seasonal Autoregressive integrated Moving Average (SARIMA) dengan Deteksi Outlier Sebagai Upaya Optimalisasi Produksi Pertanian di Kabupaten Mojokerto. Seminar Nasional : Kedaulatan Pangan dan Energi, Fakultas Pertanian Universitas Trunojoyo Madura. Bangkalan.

Badan Informasi Geospasial. 2018. Indonesia Geospatial Portal. Tersedia di: wmw.tanahair.indonesia.go.id.

Badan Pusat Statistik Kabupaten Wonogiri. 2018. Kecamatan dalam Angka 1986-2017. Tersedia di: wnw.wonogirikab.bps.go.id.

Badan Standarisasi Nasional. 2010. Spesifikasi Penyajian Peta Rupa Bumi - Bagian 3: Skala 1:50.000. SNI 6502.3.

Badan Standarisasi Nasional. 2015. Penyusunan Neraca Spasial Sumber Daya Alam-Bagian 1: Sumber daya air. SNI 6728.1

Bambang Triatmodjo. 2010. Hidrologi Terapan. Beta Offset. Yogyakarta.

Bintang Suncaka. 2013. Analisis Keandalan Metode Mock dengan Data Hujan 5, 10, 15 Harian dan 1 Bulanan. E-Jurnal Matriks Teknik Sipil. Vol 1. No 4. Universitas Sebelas Maret Surakarta.

Departemen Pekerjaan Umum Direktorat Jenderal Sumber Daya Air. 2012. Petunjuk Teknis Penyusunan Neraca Air dan Penyelenggaraan Alokasi Air. No 04/SE/D/2012.

Ig. L. Setyawan Purnama, et al. 2012. Analisis Neraca Air di DAS Kupang dan Sengkarang. Percetakan Pohon Cahaya. Yogyakarta.

Indra Kusuma Sari. 2011. Analisa Ketersediaan dan Kebutuhan Air pada DAS Sampean. Jurnal Pengairan. Vol 2. No. 1. Universitas Brawijaya Malang.

Kementrian Pekerjaan Umum Direktorat Jenderal Sumber Daya Air. 2013. Kriteria Perencanaan Jaringan Irigasi (01). Jakarta

Kodoatie, R.J dan Sjarief, R. 2010. Tata Ruang Air. Yogyakarta: Andi.

Mock, F.J. 1973. Land Capability Appraisal Indonesia. Water Avaibility Appraisal Report Prepared for the Land Capability Appraisal Project. Bogor-Indonesia.

Rintis Hadiani. 2009. Analisis Kekeringan Berdasarkan Data Hidrologi. Disertasi. Universitas Brawijaya Malang.

Sri Harto. 1993. Analisis Hidrologi. Jakarta : PT. Gramedia Pustaka Utama. 